\title{
De bois e outros bichos: nuances do novo Realismo brasileiro Tânia Pellegrini ${ }^{1}$
}

\author{
Perhaps even realism is now extremism, \\ since extremism is the way \\ of the world. \\ Terry Eagleton \\ Não estamos alegres, é certo. \\ Mas também por que razão \\ haveríamos de ficar tristes? \\ V. Maiakovski
}

\section{Realismo e violência}

Tentando encontrar rótulos precisos que facilitem a tarefa de classificar a prosa brasileira contemporânea, tornou-se banal adjetivá-la como plural, múltipla, fértil, híbrida etc., como se esses termos não tivessem sido antes aplicados a qualquer outro período da história da cultura ou da literatura, nos quais também não era ainda possível estabelecer consensos sobre características dominantes, posto que, sempre, vêm juntas as residuais e as emergentes. Além disso, tem havido certa pressa em determinar balizas temporais que afinem a aplicação dos rótulos, tais como "a partir da década de 1990" ou "no século XXI", eliminando rapidamente quaisquer identificações anteriores, como se "contemporâneo" se referisse ao presente mais imediato, como se o fluir do tempo tivesse sido estancado e, de repente, uma nova era de fato tivesse começado. São termos pret-à-penser, que elidem os achados de uma lenta acumulação, tensa, contraditória e pluridisciplinar de saberes sobre o assunto, reforçando a sensação de uma certa frivolidade do objeto. Considerando-se que o desenvolvimento das formas artísticas se dá em processo e que, nele, o binômio continuidade/ ruptura é determinante, pois uma não existe sem a outra, acredito que o qualificativo mais adequado - pois apesar de tudo é necessário escolher um -, seja transitório. Isso porque o conjunto dessa prosa de fato plural,

\footnotetext{
${ }^{1}$ Coordenadora do Programa de Pós-Graduação em Estudos de Literatura, docente do Departamento de Letras e do Programa de Pós-Graduação em Sociologia da Universidade Federal de São Carlos (UFSCar), São Carlos, Brasil. E-mail: tpelleg@uol.com.br
} 
Tânia Pellegrini

fértil e híbrida, enquanto aparenta romper vários cânones estabelecidos, transitando pela história, conserva-os ciosamente, mesmo se muitas vezes revisitados, o que transforma também seu uso e função.

Um desses cânones é o Realismo, cujos temas retirados da matéria social com muita frequência têm sido elaborados sobre os tons e semitons da violência. Isso leva a cogitar que continuamente vêm emergindo novas formas de realismo, multifacetadas e complexas, procurando dar conta de representar ordens reiteradas da experiência humana, agora peculiares às sociedades contemporâneas. Assim, não há como negar a presença ainda de condições sociais bastante semelhantes àquelas do "mundo hostil" do qual surgiu o realismo, tornando o problema da representação menos simples do que parece.

Vale brevemente lembrar que, desde o seu surgimento como estilo, no bojo do Positivismo, realismo tem sido usado para definir qualquer representação artística disposta a "reproduzir" o mundo concreto e suas configurações. E, de modo geral, aceita-se que ele emergiu de um processo histórico-social específico: a ascensão da ideologia burguesa europeia, dando forma própria à cultura e trazendo o povo para o centro da cena, com uma postura politicamente rebelde. Libertário, subversivo, confiante, contestador de tradições e instituições, encarnava então o que havia de mais moderno em arte e literatura. Assim cresceu e se ramificou, fazendo da objetividade da experiência, da vida quotidiana e da luta do indivíduo contra um "mundo extremo" seu tema preferencial.

O que se modificou aos poucos, ao longo do tempo, foram as posturas e os métodos adotados pelos criadores, os traços mentais e afetivos que imprimiram às obras, a escolha e a disposição dos detalhes da vida quotidiana observados, em suma, a organização e articulação coerentes dos materiais representados, consubstanciando uma inter-relação dialética entre indivíduo e sociedade, em cada momento. Especificamente no Brasil, o Realismo vem acompanhando, em longo percurso e com modificações significantes, as alterações da sociedade e de regimes políticos, que passaram da aparente circunspecção e conservadorismo do império agrícola às agitações industriais modernistas, para atravessar depois duas ditaduras "modernizantes" e ingressar, com a volta da democracia, na era do livre mercado e da imagem eletrônica.

Nesse longo percurso, a violência caminhou pari passu, constituindo-se não apenas como dado para a compreensão da própria dinâmica social brasileira, mas também como representação, nutrindo a movimentação específica da produção cultural e literária. O que se vê como novidade, hoje, na relação entre violência e representação, são sua concretude e seus 
modos de manifestação: tanto a violência real quanto a representação violenta, via realismo, parecem vir de toda parte, atingindo os mais diferentes segmentos sociais e eclodindo em qualquer contexto. Enquanto representação, afirma-se como elemento discursivo e estilístico peculiar à contemporaneidade; brota com ímpeto e incidência antes insuspeitados, traduzindo, inclusive, subjetividades diferentes das tradicionalmente envolvidas com arte e literatura ${ }^{2}$, e indicando, em letras e imagens, uma espécie de "normalização" estética do lado mais trágico da sociedade brasileira, por meio da insistente reiteração do conflito, do confronto e mesmo da crueldade e da barbárie.

O primeiro tópico a ser enfrentado aqui é o da definição de violência. Tão complicado quanto o da definição de Realismo ${ }^{3}$, para ele, existem várias respostas possíveis, evidenciando clivagens que tangenciam a Sociologia, a Antropologia ou a Filosofia; a mais adequada, porém, para os propósitos deste ensaio, parece ser considerar violência como ação física voluntária entre indivíduos, causando dor ou danos físicos ou mentais de qualquer tipo. Trata-se de uma definição que se baseia na concretude do ato violento - se assim podemos dizer - sendo aquela que mais se relaciona a certas formas "diretas" de representação realista. Contudo, há outro conceito a considerar, a "violência simbólica", presente nos símbolos e signos culturais em geral (Bourdieu, 2004); trata-se de uma "doce violência", nem sempre percebida como tal, que se dá pela ação de reforço das próprias normas sociais internalizadas, concretizando-se pelo consentimento. Ela age de modo indolor, invisível e eufemizado, interferindo na formação e transformação dos esquemas de percepção e de pensamento, nas estruturas mentais e emocionais, ajudando a conformar uma visão de mundo.

Seguindo esse enfoque, acredito que um bom modo de tornar mais clara a argumentação sobre o nó inextricável entre a realidade da violência e suas formas de representação, na literatura de hoje, seja mergulhar em algumas das chamadas "narrativas da violência". O termo mergulho indica a pretensão de perceber, ou talvez ainda apenas intuir, no exíguo espaço destas páginas, a ligação entre a forma dessa literatura (o Realismo

\footnotetext{
${ }^{2}$ Refiro-me especificamente ao conjunto que se abriga sob o termo "literatura marginal", com suas características próprias, que possui já bibliografia abrangente.

${ }^{3}$ Assumo o Realismo, na perspectiva de Raymond Williams, como um tipo de narrativa que cria e atribui valor às especificidades de um modo de vida, em termos das características específicas dos sujeitos, conferindo o mesmo valor ao conjunto da sociedade de que eles fazem parte. Enfatiza-se assim a organização e o amálgama de diversas modalidades de experiência representadas: individual e social, subjetiva e objetiva, reflexiva e prática, pessoal e geral, uma refletida na outra, de modo a compor uma visão do todo. Ver Pellegrini (2009).
} 
Tânia Pellegrini

e seus modos) e as configurações (sociais e culturais) que a geram e alimentam, pois determinadas formas de relação social estão profundamente incorporadas às formas artísticas. Método fácil de formular, mas difícil de cumprir, pois o que parece geral e semelhante, na verdade, pode diferir em inumeráveis aspectos.

Explicando melhor: uma das maneiras de procurar circunscrever a alardeada multiplicidade de tendências temáticas e formais da prosa contemporânea tem sido utilizar alguns traços conceitualmente bastante vagos, tais como desintegração, desordenação, desterritorialização, descentralização, desrealização $0^{4}$. O prefixo des marca a tentativa de destruição de tudo o que é sólido, peculiar ao pós-modernismo, implodindo a realidade concreta representada, evidenciando as zonas de sombra dos pontos de vista, vale dizer, das subjetividades, das fímbrias e fissuras do dito e não dito, assim destacando disparidades e pluralidades de posturas e procedimentos de escrita. Alegadamente, uma estética que se erige sobre os escombros do real, considerado muitas vezes até inexistente, o qual, entretanto, reitera vivamente sua existência nessas mesmas ruínas, testemunhas vivas de um mundo concreto que resiste... mesmo como escombro.

Assim, parcela significativa dos novos autores, dos novíssimos, dos emergentes e dos apenas aspirantes pode ser aglutinada como tributária direta ou indireta desse prolífico tema, os escombros do real, vistos como rejeitos de um projeto que não se cumpriu. Neste ponto, é importante ressaltar que a premência desse tema e seu gosto realista vinculam-se principalmente ao processo de expansão e transformação das cidades, em todo o mundo, criando imensos e problemáticos contrastes entre a riqueza e pobreza, num mesmo espaço; um novo complexo de relações físicas e psicológicas, expressos na geografia de bairros nobres cercados por comunidades pobres, em morros, ruas e becos, com barracos e cortiços perigosos, onde se atravancam trabalhadores e desocupados, muitas vezes vindos do campo, de regiões ou de países distantes. Uma realidade de vício, violência e desespero para os menos afortunados, de medo explícito ou inconsciente para os outros, mas de insegurança intensa e geral para todos, que se instala e espraia, devido à concentração acelerada e febril de uma modernização poucas vezes inclusiva. Ruínas do projeto modernizante. Vale lembrar que não é um fenômeno novo; remonta ao início da revolução industrial.

No caso brasileiro, como se sabe, esse processo foi e tem sido o mes-

\footnotetext{
${ }^{4}$ São termos bastante utilizados nas análises referentes à arte e à literatura contemporâneas, sob o signo de algumas concepções de pós-modernismo, denominação sobre a qual, como se sabe, existem inúmeras interpretações.
}

40 estudos de literatura brasileira contemporânea, n.39, jan./jun. 2012, p. 37-55 
mo: a violência vem sendo a viga mestra da organização e funcionamento da nossa própria ordem social, simbolicamente representada na história e na tradição da literatura nacional. A despeito das interpretações que preferem elidir os conceitos de história e nacionalidade, englobando tudo num universo multicultural e a-histórico, descolado das especificidades configuradoras de cada sociedade - aliás, globais elas próprias, o que complica o quadro - , no meu modo de ver, a violência de que fala a prosa brasileira de hoje (não sendo, por certo, elemento exclusivo dela), é um dado sintomático das peculiaridades específicas do processo excludente da modernização capitalista que aqui se cumpriu.

\section{O homem lobo do homem}

Tentando evidenciar, como tarefa crítica, os argumentos esboçados acima, selecionei dois contos de Marçal Aquino, autor cuja obra condensa vários aspectos significativos do problema até aqui exposto. Bastante acessível à mídia em geral, como é comum atualmente, Aquino costuma fazer declarações interessantes, que funcionam muitas vezes como bons indícios a sondar:

Preciso do estímulo da realidade. Ela dispara a centelha da ficção dentro de mim. A vantagem do escritor realista hoje é que ele pode propor qualquer situação, por mais absurda que seja, que ela vai ser sancionada pela realidade. O roteirista da vida real ganharia o Oscar todo ano. Participei de uma coletânea sobre os dez mandamentos com o tema "não cobiçarás os bens alheios". Escrevi sobre dois mendigos, porque vi dois deles batendo boca, disputando o espaço sob o viaduto. Outra vez estava na fila do banco e vi um mendigo sentado no poste. Uma mulher se agachou para falar com ele. Bolei a história de uma professora da USP que o acolhe em casa por piedade e acaba se apaixonando por ele, que tem um certo refinamento. Chama-se "A exata distância da vulva ao coração" e vai virar filme ${ }^{5}$.

Provavelmente quando se refere aos dois mendigos, está remetendo ao conto "Boi", publicado na coletânea Famílias terrivelmente felizes (Aquino, 2003). Nesse texto, existe uma dedicatória: "Homenagem a João Antônio (1937-1996), poeta dos escombros do mundo". O outro mendigo mencionado figura em Aquela canção, outra coletânea, em que vários autores fo-

${ }^{5}$ Citado em: <http://loucurasdeladylita.blogspot.com>. Acesso em: 4 jan. 2011. 
Tânia Pellegrini

ram desafiados a criar um enredo, sob a inspiração de canções populares brasileiras, utilizando melodia e letra como contraponto ${ }^{6}$.

No primeiro conto, "Boi", tem-se uma crua operação de compra e venda entre dois mendigos, que vivem entre as ruínas da vida urbana. Boi é um deles: "Estava sempre inchado - de cachaça e das bordoadas da vida. Daí o apelido: Boi" (id., p. 183). Costuma dormir sob uma marquise, exposto a tudo, virando-se com papelões, e deseja o conforto do barraco de Eraldo, localizado debaixo de um viaduto: "de longe, o melhor barraco das redondezas" (id., p. 184); resolve oferecer por ele um revólver encontrado num matagal. Recusada a oferta, Boi tenta usar a arma em outra compra: oferece-o a dois homens, em troca da expulsão de Eraldo; este, além de um nome humano e uma propriedade, também tem capital de giro; consegue comprar com dinheiro guardado a morte de Boi, pelos mesmos homens. Todavia, numa reviravolta imprevisível, Boi atira nos homens, que fogem; volta ao barraco, golpeia Eraldo, que bate a cabeça em uma pedra. Vitorioso, Boi passa a noite no barraco, agora seu. No dia seguinte, porém, chegam operários avisando que ele seria demolido, para reparos no viaduto. Sem saída, Boi mata-se com um tiro. No final, Eraldo, levado a um hospital, fica para sempre preso a uma cadeira de rodas:

Eraldo vive hoje num asilo. Divide um quarto com mais três velhos e dorme numa cama com lençóis sempre cheirosos - são trocados toda segunda-feira. Ele não consegue falar, sequela da pancada na cabeça. Só baba e repete uma única palavra. O tempo inteiro. No começo, seus companheiros de asilo riam. Depois acharam que ele estava tentando informar seu apelido. Então passaram a chamá-lo de Boi. (id., p. 193-4)

Aquino ficou conhecido especialmente por utilizar a violência como leitmotif de seus contos, romances e roteiros de cinema, na esteira da matriz criada muito antes por João Antônio, por ele homenageado acima, em cuja ficção já vicejava uma pilantragem miúda, gestada e nutrida pela desigualdade social. Outra matriz já exaustivamente estudada é Rubem Fonseca, que aprofunda essas feridas, introduzindo uma crueldade descarnada e fria em relação ao ser humano, até então inédita em nossa pro$\mathrm{sa}^{7}$. Aqui a periodização é clara e funciona como baliza crítica para o termo "contemporâneo": um recuo cronológico de mais ou menos cinquenta

\footnotetext{
${ }^{6}$ Aquino escolheu "Último desejo”, de Noel Rosa, cuja letra inclui os seguintes versos: "perto de você me calo/ Tudo penso e nada falo/Tenho medo de chorar/ Nunca mais quero seu beijo/ Mas meu último desejo/ você não pode negar" (Nestrovski, 2005, p. 58).

${ }^{7}$ Ambos os autores publicam seus primeiros livros em 1963: Malagueta, Perus e Bacanaço, de João Antônio e Os prisioneiros, de Rubem Fonseca.
} 
anos remete aos anos 1960, à ditadura militar e seus desdobramentos na formação do Brasil de hoje, visível também nas questões culturais e literárias ${ }^{8}$.

É impossível negar que a violência, tanto direta como simbólica, sai então da coxia, onde ensaiava ainda lenta e mais individualizada, assumindo o papel de protagonista destacada e coletiva da ficção a partir desse período. O projeto hoje vitorioso de inserção do país no circuito do capitalismo avançado, com seus milagres tecnológicos e promessas de felicidade geral, gerou contradições sociais insolúveis, que explodem em violência e são traduzidas no cinema e na literatura, nas múltiplas variantes realistas. Quase trinta anos depois, Aquino começa a publicar contos e romances, na esteira desses realismos, depois de incursões pela literatura juvenil e por um livro de poemas ${ }^{9}$. Traz na bagagem as lições do jornalismo exercido nas editorias policiais e de comportamento ${ }^{10}$, o que modela sua prosa ágil, irônica e desconcertante.

Quase sem retoques ou mediações, traduz realidade em ficção com frases breves e secas, diálogos certeiros, de ritmo acelerado e leve, apesar do peso da "matéria vivente", como diria Rosa. Utilizando com habilidade as tradicionais categorias estruturantes da narrativa, desenha uma arquitetura sombria, com personagens sempre envolvidas em alguma disputa ou vingança, que ocorre em tempos e lugares concretos, embora indeterminados: grotões distantes ou ruas, becos e antros, num eterno presente sem futuro, ratificando a ideia dos escombros do mundo. Por isso, estão ausentes as descrições minuciosas, que Barthes recrimina como "pormenores inúteis", pois destinadas a produzir o tradicional "efeito de real"11; elas, de fato, aqui não são mais necessárias, pois a realidade de que partiriam é de todos sobejamente conhecida e parece aspirada diretamente para dentro da narrativa. O realismo de Aquino, então, é visceral e de outro tipo: suga o real concreto, quase sem mediação, em cenas e movimentos rápidos, shots curtos, falas mínimas, manejados por narradores em primeira ou terceira pessoa, que sabem muito bem do que estão

\footnotetext{
${ }^{8}$ Abordei essas questões em livros anteriores: A imagem e a letra - Aspectos da ficção brasileira contemporânea, e Despropósitos - Estudos de fição brasileira contemporânea.

${ }_{9}^{9}$ Seu primeiro livro de contos, As fomes de setembro, foi publicado em 1991. Seguem-se $O$ amor $e$ outros objetos pontiagudos (1999), Faroestes (2001), Famílias terrivelmente felizes (2003). Escreveu também os romances $O$ invasor (2002), Cabeça a prêmio (2003) e Eu ouviria as piores notícias de seus lindos lábios (2008), vários deles transformados em filmes.

${ }^{10}$ Trabalhou nos jornais A Gazeta Esportiva, O Estado de S. Paulo e Jornal da Tarde.

${ }_{11}$ "Tudo na narrativa é significante, e caso contrário, se subsistirem no sintagma narrativo áreas insignificantes, qual é, definitivamente — se assim se pode dizer — a significação dessa insignificância?” (Barthes, 1984, p. 90).
} 
Tânia Pellegrini

falando, sem tergiversar com preciosismos discursivos ou rarefações psicologizantes. Tudo bastante cinematográfico (fala-se em "contaminação de meios") e facilmente reconhecível por qualquer leitor; tudo simples, claro, objetivo, articulado com a agudeza quase científica de um observador naturalista, sem complacência para com o real concreto.

Eraldo estendeu o braço com a lanterna. Quando Boi curvou-se para alcançá-la, Eraldo girou o braço e golpeou. Mas, num movimento ágil, a despeito de seu tamanho, Boi se esquivou. Eraldo é que perdeu o equilíbrio com o golpe em falso. E, depois de escorregar, rolou pela encosta. Até parar de repente. Com a cabeça numa pedra. (id., p. 191)

Desse modo, da palavra certa, na frase exata, em ritmo abrupto, a violência estala sem misericórdia.

Pode-se dizer que, no conto em questão, assoma a reedição de um tema do pensamento político clássico, desenvolvido por Thomas Hobbes: o estado de guerra constante, que torna o homem "lobo do homem", aqui metaforicamente associado ao problema da miséria:

Desta guerra de todos os homens contra todos os homens também isto é consequência: que nada pode ser injusto. As noções de bem e de mal, de justiça e injustiça, não podem aí ter lugar. (...) Outra consequência da mesma condição é que não há propriedade, nem domínio, nem distinção entre o meu e o teu; só pertence a cada homem aquilo que ele é capaz de conseguir e apenas enquanto for capaz de conservá-lo. (Hobbes, 1974, p. 81)

Premidos pela categoria do "não ter", ou seja, da escassez ou da falta, os personagens do conto vivem esse estado de guerra, articulando ações cujo único objetivo é tentar superá-lo a qualquer custo; isolados e em luta permanente, eles cercam e protegem seu território, vivendo o "constante temor e perigo de morte violenta", pois, não havendo a quem recorrer, a vida não tem garantias e nem se reconhece a posse de nada. A ação de um é limitada apenas pela força do outro; seus atos, todos ligados à necessidade de sobrevivência entre ruínas, são ditados por seu "estado natural", não importando se envolvem violência e sangue, desde que a única lei válida é a força. A cidade assim representada, por onde perambulam esses personagens, na verdade é uma aglomeração humana, que expulsa os menos aptos; não por acaso já chamada de "cidade escassa" (Carvalho, 2000, p. 55), é a que se torna palco de disputa generalizada e bruta entre os habitantes, pois ela não consegue mais contê-los minimamente sob sua lei, guarda e proteção. Aqui, se há desterritorialização, desrealização ou 
descentramento, não acontecem no sentido comumente conferido a esses termos; pelo contrário, trata-se da representação de territórios concretos, reais, fechados e centrados em si mesmos, sem saída - a parte pelo todo -, metaforizando todos os lugares em que "a vida do homem é solitária, pobre, embrutecida e curta" (Hobbes, 1974, p. 80).

\section{O bode expiatório}

A cidade escassa parece tornar-se assim o palco ideal para a encenação da guerra social brasileira, em uma espécie de "retorno do trágico", não exclusivo da literatura, que há tempos se exibe insistentemente na televisão, nos jornais, no cinema e inclusive no teatro (Resende, 2008, p. 30). Isso levanta algumas suspeitas: o que faz, em meio ao ceticismo aleatório e a frágil leveza da sensibilidade pós-moderna, esse gênero ancestral, baseado na fatalidade cósmica, no peso do destino, na seriedade e nobreza mais elevadas? Pois não é a tragédia o lugar do sofrimento e castigo de heróis bem nascidos e deuses vingativos, da catástrofe e da transgressão do ordenamento divino? Na verdade, o termo tragédia, como indica Terry Eagleton (2003), hoje pode significar simplesmente algo como "muito triste", aplicado também a acontecimentos quotidianos reais, como uma chacina, um deslizamento de encosta ou o desmoronamento de um prédio, o que complica as coisas, pois uma análise literária de cunho sociológico deve prender-se também a questões da realidade social, de caráter "moral", digamos, e não só às da teoria dos gêneros, "normativas". Nesse caso, é importante frisar que normativo ou moral, o termo tragédia, hoje, trai um subtexto sensacionalista, uma aura de violência ou exotismo, de emoções fortes e sensações proibidas, até de prazeres eróticos reprimidos, que, de modo relutante, denunciam seu parentesco com o melodrama (Eagleton, 2003, p. 9). Voltaremos a este ponto mais adiante.

Pode-se dizer, nessa linha, que o "retorno do trágico" baseia-se em um conceito contemporâneo de tragédia, de raízes aristotélicas já muito remotas, envolvendo uma visão de mundo histriônica, que sobrevive como desafio a qualquer ordem cívica ou moral. Nos termos de Raymond Williams:

trata-se de uma forma específica extremamente condicionada, de um tipo profundo, que se tornou, por assim dizer, propriedade cultural bastante geral, pertencendo mais a sociologia da nossa espécie, em determinado nível de desenvolvimento cultural, do que à sociologia específica de uma dada sociedade, num certo local $\mathrm{e}$ época. (Williams, 2000, p. 149) 
Tânia Pellegrini

Contudo, ele adverte que essas formas mais profundas não podem ser abstraídas do desenvolvimento social geral, tanto quanto não podem ser reduzidas a condições meramente locais. É em relação a essa dialética que procuro avançar.

Em termos gerais, sendo ainda o núcleo da tragédia o drama (ação), baseado na desmedida, na escolha mal feita e suas consequências, tem sido bastante comum, atualmente, encontrá-la em contos, que podem ser elaborados com facilidade num único momento de irrupção ou desfecho do conflito; nesse sentido, trata-se da narração de um "mundo abandonado por Deus", expressão relativa ao romance, que Lukács (s.d.) consagrou. Mas este, que ainda abriga o pathos necessário para a visão trágica, abre-se para uma multiplicidade de núcleos dramáticos alongados no tempo, instituindo infindáveis cadeias de causalidade, que podem diluir e adiar o impacto do terror e da piedade, tão necessário para a má consciência contemporânea, saturada de urgência e velocidade, que se satisfaz nos limites de um conto. Talvez esteja aí também uma das explicações do gosto presente pelas narrativas curtas. Mas não é o caso aqui de discutir a teoria do conto e da tragédia, mas de perceber de que modo e por que esta última tem se apresentado hoje como recurso eficaz na representação realista da violência.

Voltando, pois, ao texto em foco, percebe-se nele um evidente "mecanismo trágico" como ruína da tragédia ancestral, envolvendo também seu efeito catártico. De modo geral, nas tragédias, castigados os maus e premiados os bons, definidas com clareza as fronteiras entre o bem e o mal, o público - ou o leitor -, pelo terror e pela piedade, geralmente sai purificado e distanciado daquilo que sabe ser apenas representação. Entretanto, neste conto, como em muitos do autor, embora predomine o tom sombrio do mundo abandonado por Deus, que faz parte da própria estrutura da ação - e da realidade representada, daí o "realismo direto" - a gramática da tragédia foi alterada: não há bons ou maus, culpados ou inocentes; nem deuses, nem heróis, só mendigos, em estado de natureza, iguais na miséria e na ausência de qualquer princípio que não seja o instinto de sobrevivência animal, já anunciado no título: "Não era gordo. Estava sempre inchado - de cachaça e das bordoadas da vida. Daí o apelido: Boi" (Aquino, 2003, p. 183).

Mas há um componente humano, demasiado humano, nesse instinto animal socialmente nutrido: a cobiça, instigando o misérrimo a desejar a qualquer preço o que lhe falta e que parece sobrar ao apenas miserável: "Enquanto se aquecia num sol ralo, espiava a construção de madeira criteriosamente encravada no alto, sob o viaduto. Era o barraco de Eraldo. Tão bem feito que podia ser chamado de casa" (id., ibid.). 
A sutileza do verbo espiar denuncia a inveja e a cobiça, reforçadas pela expressão "tão bem feito", insinuando seu oposto, relacionado à precariedade do pouso de Boi, sob uma marquise. Embora possamos atribuir a Boi - na ânsia consolatória de rotular bons e maus - , o tradicional papel de oponente ou vilão, Eraldo não resiste a um olhar mais acurado, se tentarmos elevá-lo a herói: "O dinheiro é de vocês. Agora quero que vocês levem o boi pra bem longe daqui e batam nele sem dó. Estou pagando pela surra. Que é pra ele aprender" (id., p. 186).

Sem resquício de solidariedade, que desaparece com a desumanização, eles se atracam pela posse do barraco até a eliminação, pois são lixo, escória, refugo que a própria sociedade cria e precisa destruir para continuar a mesma. Percebe-se a organização de um discurso calcado no imaginário de um mundo pré-moderno, hobbesiano, todavia representado por uma estética "moderna", descarnada e tosca, firmada em poucos signos, animada por sujeitos quase desmaterializados, à mercê de um jogo de acasos inevitavelmente violento. É essa mistura de moderno e pré-moderno, realisticamente representada, que dá a medida da "pós-modernidade brasileira", ou seja, ela é a marca inescapável de um período da história nacional.

A "modernidade" dessa gramática textual, todavia, calcada sobretudo no seu ritmo ágil, como apontei, escora-se em recursos ancestrais, como as peripécias e catástrofes trágicas; as reviravoltas da ação, baseadas na animosidade e na disputa, estabelecem sucessivas rupturas de expectativa, frustrando incessantemente o anseio de restabelecimento do equilíbrio, já ameaçado desde o início. Assim, a violência contida, em que não se vê sangue, mas se ouvem apenas estampidos secos de um revólver, no princípio deixa o leitor aturdido, pois, além de ser levado pela celeridade das cenas, não consegue identificar um lado bom na história. Mas logo percebe, aliviado, que se trata de "outro lugar", ao qual não pertence, e de "outra gente", que não é a sua; sai da leitura consolado, banhado em suave compaixão, enfim purificado pelo rito sacrificial da escória da sociedade. A estrutura trágica do conto ganha assim alguma profundidade, que parece afastá-la do realismo sangrento de muitas narrativas "da periferia" (Cidade de Deus, de Paulo Lins, por exemplo), construídas como fotografias da situação social.

Contudo, cumpriu-se a catarse; aliviados com o happy end às avessas, livramo-nos da culpa social, voltamos para nossa zona de conforto, abrigando-nos na proteção de nossas veleidades de classe média leitora. Desse modo, tal realismo, contundente na aparência, registra, a sua maneira, um traço importante da produção cultural e literária de hoje: $o$ barateamento do trágico, que não é de modo algum seu simples retorno, mas o preço do 
Tânia Pellegrini

ingresso para o espetáculo da indústria cultural, do qual a violência direta ou simbólica é um dos atores mais bem pagos. Adorno advertira há muito tempo que a indústria programa para o trágico um lugar fixo na rotina da produção, já transformado em um aspecto aceito e calculado do mundo; assim, tanto em "Boi", como em tantas outras narrativas semelhantes, o final infeliz "torna mais clara a impossibilidade de destruir a vida real". E acrescenta:

muito longe de simplesmente encobrir o sofrimento sob o véu de uma camaradagem improvisada, a indústria cultural põe toda a honra da firma em encará-lo virilmente nos olhos e admiti-lo com uma fleuma difícil de manter (...) A mentira não recua diante do trágico. Do mesmo modo que a sociedade total não suprime o sofrimento de seus membros, mas registra e planeja, assim também a cultura de massas faz com o trágico (...). Ele nos protege da censura de não sermos muito escrupulosos com a verdade, quando de fato nos apropriamos dela com cínico pesar. (Adorno, 1986, p. 141-2)

\section{Os olhos tristes do cão}

Já o mendigo de "A exata distância da vulva ao coração", como o próprio título indica, adentra a cena em outro tom. Não traz a contundência do realismo miserável dos outros dois, não evidencia a violência direta, embora traga para dentro de um conhecido universo de classe média a cicatriz do que chamei de tragédia social brasileira. Nesse sentido, a dissimulação gradativa dessa cicatriz obriga à substituição do mecanismo trágico do enredo anterior pelo mecanismo do melodrama, embora, como antes sugeri, este já esteja ali contido. Se o realismo e a tragédia, grosso modo, confrontam a imaginação com a verdade e organizam o mundo como uma rede complexa de contradições, delimitando o poder dos homens em relação ao seu próprio destino, o melodrama vê esse mundo de outra maneira. De acordo com Ismail Xavier:

Ao melodrama estaria reservada a organização de um mundo mais simples, em que os projetos humanos parecem ter a vocação de chegar a bom termo, em que o sucesso é produto do mérito e da ajuda da Providência, ao passo que o fracasso resulta de uma conspiração exterior que isenta o sujeito de culpa e transforma-lo em vítima radical. (2003, p. 85)

De fato, o melodrama opera com base num esquema narrativo, usado no cinema e na televisão com rendimento extraordinário, que repousa nas 
vicissitudes de um inocente maltratado pelo destino, o qual, auxiliado por alguém ou buscando forças no mais fundo de si, supera a situação desfavorável: "Um nobre que tivesse perdido a maioria das contendas com a vida" (Aquino, 2005, p. 65), fantasia Marilu, personagem do conto em questão.

É o que ocorre, de fato: uma professora universitária, sozinha e carente de afetos, acolhe um mendigo que montara uma barraca de lona sob uma figueira, no canteiro central da avenida defronte sua casa. Ele tem nome: Jorge. Um nome comum, mas digno e sério, ao contrário do nome dela, Marilu, que na escansão das vogais e consoantes sugere algo de frívolo. Ela o carrega para dentro de casa; do quartinho no quintal, passo a passo, ele chega à cama da moça. Ela quer conhecer seu passado, ele nega sempre. A curiosidade de Marilu se acentua, pois ele mostra algum refinamento, escreve poemas e consegue sustentar uma conversação social; ela morre de ciúmes, pois ele faz sucesso entre as mulheres; brigam, ele volta para a barraca; reatam e, no final, ele lhe concede um "último desejo": aceita contar seu passado, em troca da permanência na casa.

O acento irônico, quase sarcástico, já presente no título, acena para o deboche, pois a palavra "vulva", ali empregada, introduz um sutil toque pornográfico, sobretudo por juntar-se a "coração", tradicional símbolo de casto amor romântico. Aquino é um escritor incrivelmente habilidoso na criação de títulos para suas narrativas, a maioria deles articulados com muita originalidade. Desse modo, de imediato coloca o leitor em expectativa, pronto a mergulhar no que tem a contar. Aqui, logo na primeira linha, a expectativa, já mesclada à excitação causada pelo termo erótico, aumenta sensivelmente:

O homem e o cão tinham olhos tristes. Marilu viu os dois de manhã quando saía com o carro da garagem do sobrado. (...) As posses do homem amontoadas num carrinho de supermercado. A barba e o cabelo ocultavam seu rosto (...). À noite, de volta da universidade, ela reparou no abrigo improvisado com um pedaço de lona amarela. O mendigo fixava residência no bairro. (id., p. 59)

Os olhos tristes do cão e do homem têm algo de chapliniano. Certa doçura que amolece, logo desmentida, porém, pois na verdade "o mendigo era estrábico". A excitação e a expectativa juntam-se agora à curiosidade, pois surgiu um enigma, elemento básico de narrativas policiais. Quem será esse mendigo? O que fará Marilu? Sofrerá algum tipo de violência? Qual será o desenlace do entrecho? Mesclam-se, assim, resquícios de an- 
Tânia Pellegrini

tigos gêneros populares: as "novelas de sensação", com dramas emocionantes e crimes hediondos, as "leituras para homens", cujos temas giravam em torno de sexo, prostituição etc. (El Far, 2005), a narrativa policial e a comédia.

Restava a Marilu aventar hipóteses: talvez Jorge fosse um jogador compulsivo, desses que perdem tudo no baralho, até a família. Outra hora pensava nele como alguém que desistira do mundo depois de enfrentar uma grande dor (...). E se fosse um psicopata? Ela se perguntava. Um fugitivo do manicômio? (Aquino, 2005, p. 70)

A inserção do "elemento trágico" masculino, marcado pela queda e pela desdita não explicitadas, que o transformaram na vítima melodramática por excelência, funciona como um coeficiente de realismo sério no quotidiano doméstico de uma mulher de classe média instruída - retratada com ironia, segundo estereótipos de gênero - , aparentemente por vontade desta, verdadeira encarnação da Providência. O esquema narrativo montado elimina a contundência da experiência social que, mal ou bem, permeia o primeiro conto; o aparente realismo esbarra na pouca verossimilhança do fato nas condições brasileiras: pessoas de classe média não costumam recolher em casa um morador de rua. Mas é o inusitado da situação que espicaça o leitor e o narrador justifica o ato de Marilu com a bonomia da moça e a limitação delicadamente atenuada de seus predicados físicos:

Não que Marilu fosse feia, longe disso. Os traços de seu rosto eram graciosos, delicados, e sua boca do tipo carnuda. Seus olhos escuros tinham inteligência e o mesmo brilho de seus cabelos sedosos. O problema era a balança. Alguém que se referisse a Marilu como "aquela gordinha" não poderia, de forma nenhuma, ser processado por calúnia. (id., p. 61)

O leitor acompanha pressuroso o gradual avanço de Jorge da barraca para o quartinho dos fundos, em seguida para a mesa e cama e, finalmente, da vulva para o coração de Marilu. Espera sangue e morte no final - bombardeado que é por enredos semelhantes no cinema e na TV -, mas sofre uma reversão de expectativas, pois o desenlace previsto não acontece, relativizando os clichês do gênero. Não há crime desta vez, não há sangue. O conflito pessoal estabelecido resolve-se pelo perdão e pela reconciliação, não sem antes passar por peripécias cômicas, como o ciúme de Marilu pela faxineira: “Dia de faxineira em casa era dia em que Marilu padecia horas de azia amorosa. Um veneno que alterava seu metabolismo e seu peso" (id., p. 79). 
Mas Jorge, depois de idas e vindas, como um herói cômico, obtém seu triunfo, seja o que for que tenha feito para provocar a própria queda, tenha sido honesto ou vil, criminoso ou inocente. Ele pode ser quem for - o alazón, intruso, impostor, segundo Northrop Frye (s.d., p. 45)-, não interessa; na ambígua relação de compra e venda que se estabelece, Marilu dá a Jorge casa e comida, ele lhe dá sexo e afeição, provavelmente simulada. O conflito social latente, por sua vez, resolve-se num ato individual de solidariedade, que a ela não custou nada, só lhe trouxe benefícios:

Um ato solidário não custava nada de vez em quando, ela era dada a esses repentes. Fazia trabalhos voluntários sempre que podia, no Natal levava brinquedos para crianças em instituições assistenciais, esse gênero de coisa. Sua alma era mais bonita que seu corpo. (Aquino, 2005, p. 61).

Dessa forma, a utilização do esquema melodramático (segredos, suspense, anúncios, sinais, emoções sem freio e revelações adiadas) simplifica as graves questões em pauta na sociedade - apesar do realismo isento que Aquino advoga -, ficcionalizando a experiência dos injustiçados em clave irônica. As virtudes de Marilu são recompensadas, assim como a miséria de Jorge é dirimida; ele ascende socialmente, incorpora-se novamente à sociedade da qual fora expulso, por obra e graça de sua esperteza quase picaresca. Tal organização narrativa tem muito das convenções das tradicionais comédias domésticas e de costumes, que até hoje alimentam as telenovelas, por exemplo, em que a preocupação com dinheiro e estabilidade não pode ser desenredada de amores e apetites, reais ou fictícios.

Mesmo o final aberto, no qual Jorge aceita os termos da negociação e se dispõe a contar seu passado, seja qual for, em troca da permanência na casa, não permanece como inquietação para o leitor, pois este sabe que o acordo foi selado na "distância exata da vulva ao coração" e é isso o que importa. O que seria o reconhecimento trágico, ou seja, a revelação do passado de Jorge, não se dá para o leitor, apenas para Marilu: "Senta aqui. Eu vou contar minha história para você" (id., p. 85). Assim termina a narrativa. Pode-se dizer que o happy end executa a catarse com maestria: a simpatia e a graça purificam o leitor, que, não sendo posto a par de desgraças ou misérias que trouxeram Jorge para debaixo da figueira no centro de uma avenida, num dia de inverno, entrevê com alívio possibilidades de solução individual para a tragédia social brasileira, com base apenas no espírito cristão e na troca de afetos hipocritamente solidários. Sem uma gota de sangue. 
Tânia Pellegrini

Trata-se de uma "versão pop"12 do melodrama, que incorpora os deslocamentos de valores propiciados pelo hedonismo da sociedade de consumo, desestabiliza as normas tradicionais de relação entre os gêneros e mistura arcaico e moderno. Poderia até ser considerada paródia do folhetim, gêmeo do melodrama, mas como as intenções críticas geralmente ligadas ao termo paródia aqui são ambíguas, pode-se falar em apropriação (Meyer, 1996, p. 167), o que convém à economia da indústria, habituada a saquear todos os repertórios.

\section{Doce violência}

Nos dois contos aqui sucintamente comentados, pode-se perceber uma espécie de dispositivo compensatório ou solução esperta, comuns na ficção de Aquino; aparentando sobressaltar o leitor, na verdade ele o acalma, dirimindo-lhe medos e angústias conscientes ou inconscientes, gerados pela iniquidade social e seu fantasma maior, a violência, na medida em que o tratamento desta parece estar à vontade em relação às funções apaziguadoras exercidas pela rotina da indústria cultural e seus gêneros de eleição. No primeiro conto, o trágico encenado assemelha-se ao mal triunfante, à vitória total da violência, que, todavia, ao invés de aterrorizar, conforta, porque se encarna num bode expiatório: o "boi", cujo fim libera o leitor de sua culpa, pois traz em si todos os signos da injustiça finalmente enxotada, fechada num lugar seguro e longe dos olhos.

No segundo, o intruso ou alazón (ao contrário do que acontece nesse antigo tema) ${ }^{13}$ não desestabiliza ou destrói; é absorvido, ironicamente adequado à ordem social, graças ao espírito cristão que mascara uma operação mercantil envolvendo sexo e bens materiais; além disso, essa operação baseia-se em uma relação de gênero absolutamente conservadora, embora pareça o contrário: sob a capa de mulher emancipada, zombeteiramente desenhada, está a que anseia por uma relação tradicional, mesmo adequada aos tempos modernos; como em qualquer melodrama ou folhetim, a redenção do desafortunado se faz por obra da generosidade e do altruísmo individuais. Apesar da ironia que comanda a narrativa, o happy end, fórmula mágica da indústria, sem uma gota de sangue, mostra-se mais uma vez de grande utilidade, reiterando-se como lugar ideal para as representações suavizadas, para os acertos complacentes que têm mantido intacta a ordem social brasileira, marca de seu passado e presente. $\mathrm{O}$ dou-

\footnotetext{
${ }^{12}$ Empresto o termo de Xavier (2003, p. 88).

${ }^{13}$ Ver, por exemplo, o roteiro do próprio Aquino para O filme O invasor, de Beto Brant (2001).

52 estudos de literatura brasileira contemporânea, n.39, jan./jun. 2012, p. 37-55
} 
ble coding (Brooks, 1985), ou seja, a mistura de um "código alto", a tragédia, com um "código baixo", o melodrama, funciona à perfeição para estabelecer as regras do jogo.

Mesmo descontentes com a própria civilização, embora sem ver alternativas para ela, ambos os textos podem ser considerados, em si - pois são parte de uma indústria - , formas de violência simbólica, trazendo embutido um corpo de representações, valores e crenças, que será interiorizado e partilhado por todos, mais ou menos, consciente ou inconscientemente ${ }^{14}$. $\mathrm{O}$ traço essencial dessas narrativas, que se podem considerar conciliatórias, em termos de sua função social, é justamente abordar problemas candentes, propiciando uma interpretação redutora deles, voltada para a reprodução de preconceitos e estereótipos e não para o esclarecimento. Como se vê, é possível, assim, tocar nas "chagas sociais", "denunciá-las", sem comprometer o estado de coisas, pois o leitor é direcionado para uma catarse que, longe de ser ameaçadora, oferece uma expressão ambivalente, domesticada e reconfortante para as inquietações e medos presentes na sociedade.

A forma realista de representar, nos dois contos, expressa, portanto, uma contradição precisa nas relações sociais: o centro dos valores é o indivíduo, mas o modo de produção que o sustenta cria relações sociais diversificadas, amplas, complexas e arbitrárias. É a partir da tensão entre esses dois aspectos que se criam as nuances da representação realista contemporânea. É importante lembrar, mais uma vez, que o realismo, quando surgiu, profundamente descontente com a própria civilização, - embora sem ver alternativas para ela - , foi um movimento crítico, no qual as relações entre os homens e seus ambientes não eram apenas representadas, mas exploradas de modo ativo, constituindo a encenação de questões radicais: como vivemos, como podemos viver, como devemos viver nesse local e modo de vida especificamente palpável? (Williams, 2000, p. 170). Mesmo como estilo burguês, era o que de melhor a burguesia podia produzir naquele momento.

Hoje, sem a postura radical e o impulso coletivo do nascedouro, sem a intenção (derrotada) de penetrar profunda e criticamente na vivência quotidiana, para devorá-la por dentro - o que o próprio processo histórico destruiu -, as refrações realistas representam em profundidade as relações tensionadas entre o social e o pessoal, permeadas pela lógica mercantil, numa espécie de estratagema estético a encobrir o real - que deveria,

\footnotetext{
${ }^{14}$ É importante assinalar que a recepção, seus modos e possibilidades são pontos importantes, a respeito dos quais existe uma multiplicidade de posições, que fogem dos objetivos deste ensaio.
} 
Tânia Pellegrini

mas não pode ser mudado. Tomado dessa forma, o realismo não pode ser caracterizado de forma simplista, apenas como atraso estético e/ou conservadorismo político - tábula rasa que apaga a sedimentação histórica desse conceito - , mas sim como uma postura e um método mais uma vez em uso, cuja análise e interpretação cuidadosas podem induzir à discussão do sentido, da função e do valor de boa parte da produção ficcional do Brasil contemporâneo.

\section{Referências}

ADORNO, T. W. e HORKHEIMER, M. (1986). "A indústria cultural como mistificação das massas". In: Dialética do esclarecimento. Rio de Janeiro: Jorge Zahar.

AQUINO, Marçal (2003). Famílias terrivelmente felizes. São Paulo: Cosac \& Naify. (2005). "A exata distância da vulva ao coração". In: NESTROVSKI, Arthur. Aquela canção. São Paulo: Publifolha. BARTHES, Roland (1984). "O efeito de real”. In: et al. (Orgs.). Literatura e realidade: que é o realismo? Lisboa: Publicações D. Quixote.

BARTHES, R. et al. (1984). Literatura e realidade: que é o realismo? Lisboa: Publicações D. Quixote.

BOURDIEU, Pierre (2004). O poder simbólico. Rio de Janeiro: Bertrand Brasil. BROOKS, Peter (1985). The melodramatic imagination: melodrama and the mode of excess. Nova York: Columbia University Press.

CARVALHO, M. Alice R. (2000). “Violência no Rio de Janeiro: uma reflexão política". In: PEREIRA, Carlos Alberto M. et al. (Org.). Linguagens da violência. Rio de Janeiro: Rocco.

EAGLETON, Terry (2003). Sweet violence: the idea of the tragic. Oxford: Blackwell Publishing.

EL FAR, Alessandra (2005). Páginas de sensação. São Paulo: Companhia das Letras.

FRYE, Northrop (s.d.). Anatomia da crítica. São Paulo: Cultrix.

HOBBES, Thomas M. Leviatã (1974). In: Os Pensadores. São Paulo: Abril Cultural. v. 1.

LINS, Ronaldo Lima (1990). Violência e literatura. Rio de Janeiro: Tempo Brasileiro.

LUKÁCS, Georg (s.d.). Teoria do romance. Lisboa: Editorial Presença.

MEYER, Marlyse (1996). Folhetim: uma história. São Paulo: Companhia das Letras.

NESTROVSKI, Arthur (Org.) (2005). Aquela canção. São Paulo: Publifolha.

PELLEGRINI, Tânia (1999). A imagem e a letra: aspectos da ficção brasileira contemporânea. Campinas: Mercado de Letras/Fapesp. 
(2008). Despropósitos: estudos de ficção brasileira contemporânea. São Paulo: Annablume/Fapesp.

(2009). "Realismo: a persistência de um mundo hostil". Revista Brasileira de Literatura Comparada. n. 14, p. 11-46.

PEREIRA, Carlos Alberto M. et al. (Org.) (2000). Linguagens da violência. Rio de Janeiro: Rocco.

RESENDE, Beatriz (2008). Contemporâneos: expressões da literatura brasileira no século XXI. Rio de Janeiro: Casa da Palavra.

XAVIER, Ismail (2003). O olhar e a cena. São Paulo: Cosac \& Naify.

WILLIAMS, Raymond (2000). Cultura. Rio de Janeiro: Paz e Terra.

Recebido em agosto de 2011.

Aprovado em outubro de 2011.

\section{resumolabstract}

\section{De bois e outros bichos: nuances do novo Realismo brasileiro}

Tania Pellegrini

O texto interpreta dois contos de Marçal Aquino, "Boi" e "A exata distância da vulva ao coração", publicados em duas coletâneas diferentes, procurando verificar como o Realismo aí representa em profundidade as relações tensionadas entre o social e o ficcional. Revisitando gêneros tradicionais como a tragédia e o melodrama, de modo a acomodá-los às exigências mercantis da indústria da cultura, o autor explora o tema da violência urbana brasileira, nas suas manifestações concretas e simbólicas.

Palavras-chave: conto, realismo, violência, tragédia, melodrama

\section{About oxen and other animals: nuances of the new Brazilian Realism}

Tania Pellegrini

The article analyses two short stories by Marçal Aquino, "Boi" and "A exata distância da vulva ao coração", which were published in two different selections. It tries to verify how Realism represents in them the stressed relations between the social and the fictional. Revisiting traditional genres like Tragedy and Melodrama, in a way that accommodates them to the commercial requirements of the Cultural Industry, Aquino explores the subject of Brazilian urban violence, in its symbolic and concrete manifestations.

Key words: short story, realism, violence, tragedy, melodrama 